\title{
Possible Impossibles Between Area and Queer
}

\author{
Ragini Tharoor Srinivasan
}

Area Studies has always seemed to me rather queer. Queer in the sense that language is queer: promiscuous and ranging, given to misfires and infelicities, promising to reveal more than it can access or represent. Queer in the sense that its objects are queer: messy and incommensurable, irreducible to identitarian categories yet occasioned by identity, boundaried yet open, unbounded yet self-referential. Queer in the sense that interdisciplinarity is queer: a knowledge project premised on the destabilization of its own objects, that points to the social, historical, and political construction of the disciplines between and against which its labors are situated. Queer in that it is anti-normative. Queer in that it is impossible.

By that same token, Area Studies, that "hoary" Cold War-era "intelligence-gathering force for consolidating US power" (Arondekar and Patel 2016: 153) has always been and remains in need of queering. Queering, because those who study contemporary geopolitics and neoliberalism must attend to "the global expansion of normative society's modes of operation" (Tadiar 2016: 175). Queering, because the field's practitioners are called to "[work] with the difference of geopolitics through a notion of "difference"” and in so doing to resist "any form of totalizing knowledge" (Arondekar and Patel 2016: 155). Queering because it does not consistently, in José Esteban Muñoz's description of the queer, reject "the here and now" and insist "on potentiality or concrete possibility for another world" (quoted in Taylor 2016: 210).

"Area Impossible: The Geopolitics of Queer Studies" (GLQ 22.2) makes the case that Area Studies is queer and that it remains to be queered, while also positing Area Studies as a critical field formation with the potential to provincialize Queer Studies. The issue aims, in editors Arondekar and Patel's words, "to read the politics of queer and area studies as coincident-if not quite isomorphic-activities, to read both as heuristic practices that see form...as a placeholder that might partly express a promiscuous or incoherent desire or a desire whose content continues to be under erasure" (2016: 154). The articles, performance pieces, and aesthetic meditations assembled are consequently as interested in the signs by which they are occasioned as they are in such desires. Contributors engage with and disavow their key terms (e.g. if Taylor's "We Have Always Been Queer” owns its titular sign, then Macharia’s "On Being Area-Studied: A Litany of Complaint," refuses to accede), while questioning how translated, untranslatable, and varied knowledges travel across fields. In the process, both Area Studies and Queer Studies are defamiliarized. The queer body, readers are reminded, is not just the sexed body, but the body dismembered by the US imperial war machine and recomposed with prosthetic appendages (Mikadashi and Puar 2016: 221). "Language, organism, and race can be areas, too" (Tadiar 2016: 180).

Who, what, where and when-the issue attends equally to each interrogative-are the referents of Area Studies and Queer Studies? How might bringing these fields together enable scholars to tackle "the epistemological problem, the problem of reading, making sense of gender, race, and sexuality "in a global context"” (ibid.: 174)? The "Area" of Areas Studies is in some sense an empty signifier, or a misdirecting one. Area Studies render places into areas, an operation that jettisons the particularity and history of some "where" for what it occasions in some other('s) name. The issue gives critical and locational specificity to "Area Studies" through articles that focus on Dalit Studies, Caribbean Studies, and African Studies, while marshalling ethnographic, literary, and historical methods in service of their respective projects. Queer Studies, in turn, is distinguished 
from queer theory, characterized by some contributors as a "finite collection of ideas about destabilizing gender and sexual norms” (Currier and Migraine-George 2016: 282).

If we are accustomed to thinking of the "Area" as pointing, however provisionally, to a "where" and to "Queer" as pointing, however tentatively, to a "who," then these essays ask equally to whom the area points, and where queer directs us. How might we develop studies of areas that do not absorb queer bodies, voices, and experiences "as 'data' or 'evidence"” and read them instead "as modes of theory or as challenges to the conceptual assumptions that drive queer studies" (Macharia 2016: 185)? How might we develop Queer Studies that are not always already American in orientation, that do not reduce "areas" and their subjects to case studies, and that do not assume that the United States is "the prehensive force for everyone else's future" (Mikadashi and Puar 2016: 217)? What methods are adequate to a Queer Area Studies and an Area-aware Queer Studies that are alive to how scholarly objects, like our bodies, "betray us as much as they allow us to survive, live, love, and find each other" (Tadiar 2016: 178)?

These are some of the questions the issue provokes. Since first reading GLQ 22.2, I have returned to them often, as well as to two of the issue's many interventions. The first has to do with how thinking between Area Studies and Queer Studies might give us new purchase on the international division of labor, both economic and intellectual. On the economic question, Tadiar observes that "when some national economies are presumed and disciplined to service the needs and wants of others, sexuality is not a 'mere' metaphor but the set of regulatory precepts of regional and global trade, of transnational production and governmentality" (2016: 177). Sharma 2014 on power-chronography and Vora 2015 on gestational surrogacy and outsourcing are just two recent projects from outside Area Studies and Queer Studies that nevertheless take a consonant approach to the study of global biocapital and may be profitably read at this intersection. On the question of scholarly divisions of labor, Currier and Migraine-George's essay plumbs the pernicious divide between those Orientalists and Euro-American scholars who "know" authentic areas like "India" and "Africa" and the impure natives who study their diasporic, transnational, or otherwise hybrid derivations. This, too, is the impossible space between area and queer: the space between the desire to know, and not being able to not know it.

The second has to do with temporality as "an epistemic demeanor for the impossible nexus of area with sexuality" (Arondekar and Patel 2016: 165). Almost every essay in "Area Impossible" addresses the temporal, but Ramberg's essay on Dalit religiosity in South India is particularly attuned to how the "narrat[ion of] queer futurity" depends on fixing certain others "in the past" (2016: 243). In ethnographic readings of Dalit women married to gods, or devadasis, and Dalit converts to Buddhism, Ramberg theorizes "recombinant time," a knotted, entangled temporality that "is a way of acting in time on time to recombine its elements, producing pasts forward and backward futures" (ibid.: 235). She is particularly interested in how "backwardness" is both attributed to the Dalit community and marshalled by that community as an aspirational condition; it is also, she argues, "a sexual condition and...feature of queer existence" (ibid.: 228). The term "belated” doesn't figure in Ramberg's essay, but parallels can be drawn to key postcolonial texts that also focus on the relationship between the denial of coevalness, broadly defined (Fabian 1983), and "belatedness as possibility" (Chakrabarty 2011).

I noted above that GLQ 22.2 defamiliarizes Area Studies and Queer Studies. It also refamiliarizes those of us who do not necessarily write under the signs of "area" and "queer" with the critical potential of both. I am a scholar of South Asian Anglophonism who is not considered a South Asianist by the disciplinary conventions of Area Studies. I am a cisgendered female feminist theorist who presents as heterosexual. I am married and participating in the normative project of reproductive futurism. I'm also, as I write this, the inhabitant of a queer, brown pregnant body that 
carries within it a body that will be assigned male at birth. I'm a woman of color who is, like many of those addressed or speaking in this issue, too-frequently asked to give an account of myself.

This "burden of always having to explain" (Taylor 2016: 208) is broached in multiple essays as a condition shared by a range of non-normative, non-dominant, or otherwise marginal subjects of both Area Studies and Queer Studies. At issue are problems of language and translation, of inscrutable faces and bodies. "Women have always been explaining themselves," Taylor writes, "feminists have always been explaining themselves; people of color have always been explaining themselves; queer, transgender, and transsexual groups have always been explaining themselves; indigenous peoples have always been explaining themselves" (ibid.: 213). The injunction to explain, the imperative to yield, the expectation of making available undergirds every journey from nobody to somebody, from nothing to something, and from nowhere to somewhere.

Wilson's contribution dramatizes this journey through a scene of being seen. Wilson is in a mask, wig, and heels at a conference bar. He is questioned by a she who "sorta-know[s]" him: "Why are you hiding?" (2016: 192). The question pretends playfulness, if not quite innocence. It is asked of Wilson "simply for being present in the modes of performance in which [he] choose[s] to operate” (ibid.: 201). Why are you hiding? The question, which demands an explanation, presumes to know "you" and therefore to know that you are masked, unyielding, unavailable. It is a question that, slightly modified, speaks to decades of Area Studies scholarship: "what are you hiding?"-the gold, tea, sugar, your women in purdah-and "where are you hiding it?"

Circling what he calls "the are(n)a of the story," Wilson reflects that his "attempt was not to provide a spectacle to be seen but to disrupt the very sight of being seen in order to expand the site of my own inquiry...to mark the impossibility of the marked subject" (ibid.: 193). In this scene of being seen and not seen, of knowing what he is asked and refusing to deliver it, Wilson becomes what Macharia calls "the indifferent native," heir to "the sly native, the trickster native, the desiring native, the sage native, the undeveloped native, the homosexual native, the queer native, the deracinated native" (2016: 188), “witness to [his] own demolition” which he apprehends with an “indifferent gaze" (Chow 1993: 51-52).

The figure of the indifferent native with an indifferent gaze is one that perhaps best captures the project of "Area Impossible." Arondekar and Patel's introduction reads the poet Agha Shahid Ali on Kashmir, the embattled territory where Ali was born, caught between violently partitioned India and Pakistan, what he names "the country without a post office." "One cannot, as it were, know, or even learn about Kashmir," Arondekar and Patel write (2016: 159). Yet, "even as one cannot not know it, Kashmir provisions the possibilities for epistemology without rendering itself as knowable, as the place constantly constituted as an object for geopolitical fracases, as the denouement in the games of geopolitics" (ibid.: 162). Kashmir is area, but as area it is queer: it is and it is not; it is known and unknowable. Like the fields of Area Studies and Queer Studies, Kashmir is always already home to many, even if, finally, it belongs to no-one.

\section{References}

Arondekar, Anjali and Geeta Patel. 2016. “Area Impossible: Notes Toward an Introduction.” GLQ: A Journal of Lesbian and Gay Studies 22, no. 2: 151-171.

Chakrabarty, Dipesh. 2011. "Belatedness as Possibility: Subaltern histories, once again." The Indian Postcolonial: A Critical Reader, ed. Elleke Boehmer and Rosinka Chaudhuri. London: Routledge.

Chow, Rey. 1993. "Where have all the natives gone?" Writing Diaspora: Tactics of intervention in contemporary cultural studies. Bloomington: Indiana University Press. 
Currier, Ashley and Thérèse Migraine-George. 2016. "Queer Studies/African Studies: An (Im)possible Transaction?” GLQ: A Journal of Lesbian and Gay Studies 22, no. 2: 281305.

Fabian, Johannes. 1983. Time and the Other: How Anthropology Makes its Object. New York: Columbia University Press.

Macharia, Keguro. 2016. "On Being Area-Studied: A Litany of Complaint." GLQ: A Journal of Lesbian and Gay Studies 22, no. 2: 183-190.

Mikadashi, Maya and Jasbir Puar. 2016. "Queer Theory and Permanent War.” GLQ: AJournal of Lesbian and Gay Studies 22, no. 2: 215-222.

Ramberg, Lucinda. 2016. "Backward Futures and Pasts Forward: Queer Time, Sexual Politics, and Dalit Religiosity in South India.” GLQ: A Journal of Lesbian and Gay Studies 22, no. 2: 223-248.

Sharma, Sarah. 2014. In the Meantime: Temporality and Cultural Politics. Durham: Duke University Press.

Tadiar, Neferti X. M. 2016. “Ground Zero.” GLQ: A Journal of Lesbian and Gay Studies 22, no. 2: $173-181$.

Taylor, Diana. 2016. "We Have Always Been Queer.” GLQ: AJournal of Lesbian and Gay Studies 22, no. 2: 205-214.

Vora, Kalindi. 2015. Life Support: Biocapital and the New History of Outsourced Labor. Minneapolis: University of Minnesota Press.

Wilson, Ronaldo V. 2016. "The Are(n)a of the Story.” GLQ: A Journal of Lesbian and Gay Studies 22, no. 2: 191-204. 